\title{
EVALUATION OF BEAUTY TRAINING PROGRAMS IN REGIONAL WORK TRAINING CENTER OF EAST JAKARTA USING THE GOAL FREE EVALUATION MODEL
}

\author{
Nely Suroyya Martalena \\ Universitas Negeri Jakarta \\ Dwi Atmanto \\ Universitas Negeri Jakarta \\ Jenny Sista Siregar \\ Universitas Negeri Jakarta
}

\begin{abstract}
This study aims to determine the impact of the beauty training program in PPKD of East Jakarta on students. The impact can be seen based on three criteria, namely positive impacts according to program objectives, positive impacts outside the program objectives (side effects), and negative impacts outside the program objectives. The research method used in this study is an evaluative study using the Goal Free Evaluation model. The research subjects consisted of: managers, instructors, and beauty training participants in PPKD of East Jakarta . Data was collected using observation, interviews, and documentation. The results showed that (1) the positive impact according to the program objectives was felt by almost all training participants, namely they could increase their knowledge and skills in the field of beauty and were ready to enter the workforce, (2) a positive impact outside the program objectives freelance work as a makeup artist, having confidence in work, and daring to open a business in the field of beauty, and (3) negative impacts outside the program's objectives felt by a small number of training participants who were less serious and less focused on training that they could not accept the material taught so that they are not ready to enter the workforce.
\end{abstract}

Keywords: program evaluation, beauty training, goal free evaluation

Permalink: http://dx.doi.org/10.21831/jpv.v9i1.23301

Contact Nely Suroyya Martalena nelysuroyya@gmail.com

Universitas Negeri Jakarta, Jl. Rawamangun Muka,

RT.11/RW.14, Rawamangun, Pulo Gadung, Kota Jakarta Timur, Daerah Khusus Ibukota Jakarta 13220, Indonesia 


\section{INTRODUCTION}

Jakarta as the capital city of the country has a dense population. According to the DKI Jakarta Central Statistics Agency (Badan Pusat Statistik/BPS), DKI Jakarta residents in 2017 were $10,177,924$ people with an area of around $661.52 \mathrm{~km}^{2}$. The denseness of the population in Jakarta has made it increasingly fierce competition to get jobs with the quality of human resources (HR) needed even higher. If people cannot compete with the quality of their human resources, unemployment will occur.

Based on data obtained from DKI Jakarta Central Statistics Agency, the Open Unemployment Rate (TPT) in 2017 was 293 thousand people or 5.36 percent. That number decreased from 2016 amounting to 306 thousand people or 5.77 percent. When detailed according to districts / cities, the highest TPT is in East Jakarta at 9.13 percent. Then followed by North Jakarta and Central Jakarta at 7.31 percent and 6.51 percent.

Therefore, it is necessary to develop human resources as an effort to eliminate the gap between the capabilities possessed by the workforce and the desired work targets. The role of government is needed as an agent of development in overcoming social problems regarding human resources. According to Suyono (2014, p. 48), "The development of its essence is planned change towards a better way to improve the quality of life and human wellbeing". Therefore, the development or improvement of the quality of human resources is a very important form of development. The development or improvement of the quality of human resources can be done through the learning process in education and training activities. The learning process in education and training can change human behavior towards a better direction towards improving quality and welfare.

One of the Training Institutions established by the government as a development agent to develop the human resources needed by the work industry is the Regional Work Training Center (Pusat Pelatihan Kerja Daerah/PPKD) of East Jakarta. PPKD is a Regional Integrated Service Unit (Unit Pelayanan terpadu Daerah/UPTD) under the responsibility of Dinas Tenaga Kerja dan Transmigrasi (Disnakertrans) led by a Chief who is responsible to the Head of the Manpower Office.
PPKD has the task of conducting job training carried out both in institutional and outside training around the region and employment in the small and medium business industry. The work training program implemented is one of the government's efforts through the Manpower and Transmigration Office to address labor issues, ranging from the increase in the workforce, unemployment, employment, increasing mobility of the productive age population, to the low quality of the workforce.

Based on data obtained from the DKI Jakarta Central Statistics Agency, the DKI Jakarta Open Unemployment Rate (TPT) in February 2018 was 5.34 percent. The work force in February 2018 was reduced by 0.60 percent compared to February 2017. The highest TPT was in East Jakarta at 9.13\%. Then followed by North Jakarta and Central Jakarta at 7.31 percent and $6.51 \%$.

PPKD was built to overcome labor problems by developing human resources through training in various vocational fields that could be chosen according to the interests of the job seeker community. That way, it is hoped that it can attract many job seekers to become trainees. According to Ivan Hanavi "Vocational education and training in essence is a place to prepare a knowledgeable, skilled, and personable workforce to meet the expectations of the world of work and industry" (Hanafi, 2012).

PPKD of East Jakarta has fifteen vocational fields, one of which is the field of Beauty. The training program in PPKD of East Jakarta has 4 classes each year. In 2018, class I starts on February 26 - April 28, 2018, class II starts on April 30 - June 18, 2018, class III starts on July 23 - September 22, 2018, class IV starts on September 24 - November 282018. Beauty training is included in the new department program that was formed in 2013. Until 2018, PPKD of East Jakarta has graduated 380 Beauty training participants.

Seeing the development of an increasingly developing work world, this field of beauty is in great demand by women in general, because the field of beauty business is needed to support the appearance of modern women and can be used as a livelihood. However, the existing human resources in DKI Jakarta have not been fully fulfilled to work in the field of beauty. This is in accordance with the statement of one of the 4th generation students in 2018 who stated that she was interested in participating in 
the Beauty training in PPKD of East Jakarta because the field of beauty is currently developing and becoming a trend especially to become an artist makeup in the Capital City. By participating in this Beauty training, he hopes to be able to increase his knowledge and skills in the field of beauty so that he can compete as a competent makeup artist.

The existence of this beauty training is expected to be an instrument of human resource development that can transfer knowledge, skills and productive work ethics. The majority of students who take part in this beauty training program are young women who have just graduated from high school and housewives who are looking for provisions to enter the workforce in the field of beauty.

The existence of beauty training in PPKD East Jakarta which runs according to Governor Regulation No. 33 of 2015 concerning the Formation, Organization and Work Procedure of PPKD of East Jakarta (Gubernur Daeraha Khusus Ibu Kota Jakarta, 2015) is expected to be the right solution for job seekers (unemployed), especially young women and housewives who do not have human resources that are in accordance with the needs of the workforce and have difficulty finding work. The community that participates in the Beauty training program in PPKD is taught to include the ability of theory and practice in accordance with the demands of work, so that they can empower themselves.

The training program as one of the HR development strategies requires an evaluation function to determine the effectiveness of the training program in question. Evaluations that are often understood in the world of education and training are limited to assessment. The assessment to find out the mastery of the training material was done formatively and summatively. When an assessment has been made, it is considered that the evaluation has been done. Such understanding is not too precise. The implementation of the assessment tends to only see the achievements of the learning objectives. In fact, the educational process is not only the value seen, but there are many factors that make a program successful or not. Assessment is only a small part of the evaluation. Evaluation must also be understood as part of supervision. Evaluation does not only deal with values measured based on solving problems, but evaluation of education and training pro- grams will examine many factors. Program evaluation can be concluded as a process of information seeking, information discovery and information determination that is presented systematically about planning, values, goals, benefits, effectiveness and suitability of something with the criteria and objectives that have been set.

The evaluation model that will be used in this study is the goal free evaluation (GFE) model to determine the extent of the impact of the beauty training program in PPKD on students. This GFE model focuses on behavioral changes that occur as a result of the program being implemented, seeing side effects both expected and unexpected, and comparing with before the program is carried out.

Program evaluation is very much a model, according to the purpose of the study, the goal free evaluation (GFE) model developed by Scriven (1991) is used, which is interpreted as a reality-based evaluation or independent evaluation (Youker, Ingraham, \& Bayer, 2014). Furthermore, Scriven provides a more detailed description that in the GFE model, goals are made as an important starting point for evaluations, meaning that objectives do not have to be taken but examined and evaluated (Scriven, 1991). GFE models are also often referred to as effects model evaluations or effects models, which involve a wider scope. Stufflebeam and Coryn also explain that GFE is an innovative approach that is oriented towards consumers of evaluated programs (Stufflebeam \& Coryn, 2015).

In the GFE model the goal is to be an important starting point for evaluating, meaning that the objectives do not have to be taken but examined and evaluated. The GFE model focuses on the actual results of an activity program, not only recording the goals set, this model is able to identify the results of records that cannot be identified by the program designer. Through a blatant or hidden process the GFE model seeks to collect data in order to form program descriptions and identify accurate processes. Furthermore, Scriven provides a more detailed description that in the GFE model, the goal is to be an important starting place for evaluating, meaning that the goal does not have to be taken but is examined and evaluated (Scriven, 1991). The model can be seen in the Figure 1. 


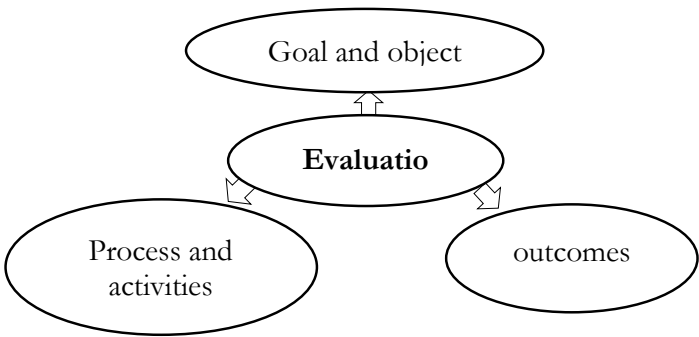

Figure 1. Adaptation from Scriven Goal Free Evaluation Model (1972)

Based on the above picture and the previous explanation it can be concluded that the use of the GFE model in this study is because this evaluation model pays attention to the impact of the program both positive and negative impacts and other side effects. The intended impact is the impact experienced by consumers or program objects or program objectives, namely students, so that the object of research is focused on students.

From the implementation of the Beauty training program, the positive impact of the program will be known, namely the impact that arises from the program that is in accordance with the objectives, negative impacts, namely unwanted negative impacts and side effects that arise that are positive but outside the program objectives. Work procedures in carrying out data mining intentionally do not focus on objectives but the program objectives are used as a platform to find out the impact of the program.

Free evaluation of objectives used by researchers based on what is done by the program, in this case the results of the implementation of Beauty training are not what the program aims to be. Goal-free evaluations have the opportunity to adjust needs to the objectives. The problems to be investigated are the results of the Beauty training program. The implementation of the Beauty training program in PPKD of East Jakarta needs to be evaluated in order to obtain an overview and the benefits and shortcomings that exist in implementing the Beauty training program for students with the existence of the program.

This Goal Free Evaluation evaluation model has its advantages and disadvantages. The strengths of the goal-free model include: (a) the evaluator does not need to pay attention to the details of each component, but only emphasizes how to reduce bias. (b) this model considers users as the main audience. Through this model, Scriven wants evaluators to measure the impressions obtained from a program compared to user needs and not compare them with advocates. (c) The influence of the concept on the community, that without knowing the purpose of the activity that has been carried out, an assessor can conduct an evaluation. (d) Another advantage, with the emergence of the free model of objectives proposed by Scriven, is to encourage consideration of any possible effects not only planned, but also other side effects that arise from the product.

However, what is proposed by scriven also turns out to have weaknesses as follows: (a) The free model of this goal is generally free to answer important questions, such as what effects have been taken into account in an event and how to identify those influences. (b) Even though good free-purpose ideas for assisting activities parallel to evaluation on the basis of honesty, at a practical level scriven is not very successful in describing how evaluation should actually be carried out. (c) Not recommending how to produce a needs assessment even if it ultimately leads to needs assessment. (d) Required evaluators who are truly competent to be able to carry out this model evaluation. (e) The systematic steps that must be taken in the evaluation only emphasize the target object. Goal Free Evaluation is a program evaluation point, where the object being evaluated does not need to be related to the object or subject's purpose, but directly to the implications of the existence of the program whether or not the object is based on an assessment of existing needs.

Written data obtained by researchers from PPKD of East Jakarta about graduates is that not all graduates are known for their work. Even though there are graduates monitoring and marketing. And the influence or impact of training participants after attending beauty training was not evaluated by PPKD of East Jakarta . Therefore, an evaluation is needed to determine the impact of Beauty training conducted by PPKD of East Jakarta to assess and make improvements needed in Beauty training activities.

From the background above, there are a number of issues that need to be examined, including: (1) how is the implementation of a beauty training program viewed from the components of socialization, selection, training, certification, marketing and monitoring?, (2) 
what are the results (results) from the implementation of the PPKD of East Jakarta beauty training program based on three criteria, namely positive impacts in accordance with the program objectives, positive impacts outside the program objectives (side effects), and negative impacts beyond the program objectives?

This study aims to obtain information about the implementation of the PPKD of East Jakarta beauty training program and its impact on training participants seen based on three criteria, namely (1) positive impacts according to program objectives, (2) positive impacts outside the program objectives (side effects), and (3) negative impacts outside the objectives program evaluation using the Target Free Evaluation model.

The benefits of this research are that decision makers and interested parties can obtain information about the effectiveness of the PPKD of East Jakarta beauty training program in terms of socialization, registration, selection, training, certification, marketing, and monitoring components so that later can make improvements or improvements to the implementation beauty training program in PPKD of East Jakarta based on several recommendations that have been given.

There are several results of the research behind this research, one of which is research about the use of the Goal Free Evaluation model in evaluating superior school programs SMAN 2 Sangatta Utara with the acquisition of research results that are positive impacts and side effects greater than the negative impact, indicating that the program has succeeded but the negative impacts that arise still must be considered and corrected so as not to disturb the stability of the program that has been good (Rubito, 2016). In addition to the research behind this research, there are also studies related to this research, one of which is research on efektivitas Program Pelatihan Kecakapan Hidup (life skill) bidang tata rias pengantin pada remaja putus sekolah di Lembaga Kursus dan Pelatihan (LKP) Kota Cimahi Provinsi Jawa Barat (Ramadhania, 2016). The research has similarities to those carried out by researchers in terms of the object under study, namely about training in cosmetology or beauty skills. The difference lies in the purpose of the research, where research conducted by Ramadhania (2016) aims to obtain descriptive re-sults/descriptions of the extent of the effec- tiveness of the training program, while the research conducted by researchers aims to determine the impact of the training program. Research on beauty or cosmetology training is rare because the field of beauty in the world of education is relatively new. Therefore there is a need for the role of students, students, lecturers, and re-searchers to conduct research in the field of beauty because of the growing age making the field of beauty increasingly influential in the world of education, development, economics, social and so on. From some of the problems expressed in the implementation of beauty training and the study of some of the results of previous research that are relevant and the background of this research, the researchers were interested in conducting research on evaluating the beauty training program in PPKD of East Jakarta using the Goal Free Evaluation model.

\section{RESEARCH METHOD}

This research is a study that uses a qualitative approach, because in the implementation of this evaluation will look for deep and extensive information to get a comprehensive picture of an object being evaluated. The object evaluated was the PPKD of East Jakarta beauty training program in terms of the components of socialization, selection, training, certification, marketing and monitoring.

The research method used in this research is evaluative/evaluation studies, because they want to evaluate a program / activity in one particular unit, in this case is beauty training conducted in PPKD East Jakarta. The research design used in this study is the Goal Free Evaluation evaluation model. The research period is conducted for 10 months from February to November 2018. Subjects involved in this study consisted of: 2 managers, 3 instructors, and 15 beauty training participants in PPKD of East Jakarta .

The method of data collection is done by observation, interviews, and documentation. Data analysis on evaluation of the beauty training program in PPKD of East Jakarta was reviewed from the components of socialization, registration, selection, training, certification, marketing, and monitoring. The data analysis technique used is qualitative descriptive data analysis of Miles \& Huberman's (1994) models which can be described as follows: 


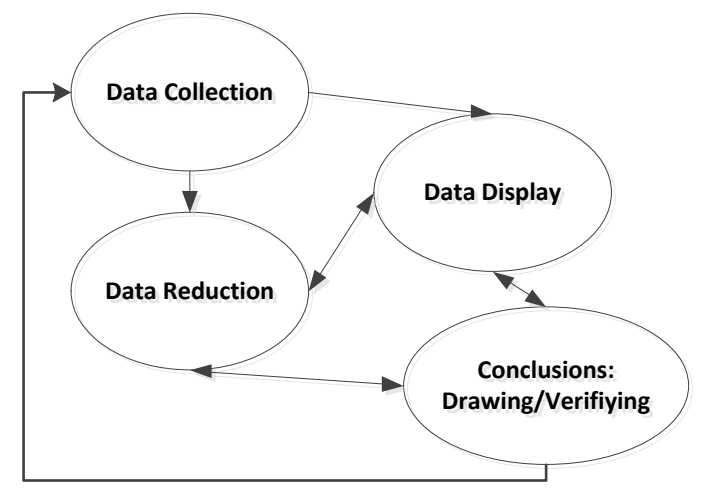

Figure 2. Qualitative descriptive data analysis model of Miles dan Huberman

(Miles \& Huberman, 1994)

The validity of the data uses data triangulation. In order for the results of the study to be really good, the collected data must have conditions, namely credibility. Strategies to increase data credibility include extension of observation, persistence of research, triangulation, analysis of negative cases and member checking.

\section{RESEARCH RESULTS \& DISCUSSION}

Based on the evaluation study of the beauty training program in PPKD of East Jakarta using the Goal Free Evaluation model, there are several things that have been evaluated including the socialization component, including: evaluation of the media used to disseminate information about beauty training in PPKD of East Jakarta and evaluation of socialization activities to the community conducted by PPKD of East Jakarta to the community. Judging from the selection component, it includes: evaluating the suitability of the training participants' registration requirements in participating in the selection and evaluation of the selection flow that the trainee must pass. Judging from the components of the implementation program, including: evaluation of the readiness of facilities and infrastructure used in the implementation of training, and evaluation of the process of implementing beauty training in the classroom. Judging from the competency test or certification component, it includes: evaluation of the PPKD competency test and evaluation of BNSP competency tests. Judging from the marketing component, it includes: an evaluation of the industry that works with PP$\mathrm{KD}$ to market graduates of beauty training and evaluation of graduates' jobs through PPKD of East Jakarta. Judging from the monitoring component, it includes: evaluation of the presence of communication media between graduates and PPKD and evaluation of job vacancy information provided by PPKD of East Jakarta. For more details about the components and aspects that have been evaluated in the implementation of the beauty training program in PPKD of East Jakarta can be seen in Figure 3.

In evaluating beauty training in PPKD of East Jakarta using the Goal Free Evaluation model, researchers collected data using the method of observation, interviews, and documentation. Through this method, then the results of the evaluation of each component of the beauty training program can be seen as seen in Table 1.

Based on the evaluation of the implementation of the beauty training program in PPKD of East Jakarta using Goal Free Evaluation, the results of the training participants were obtained after participating in beauty training. These impacts include:

\section{Positive Impact According to Program Objectives}

The purpose of this PPKD of East Jakarta beauty training program is to form human resources who are ready to enter the world of work in the field of beauty. Based on interviews with 15 trainees, the evaluation of the implementation of the beauty training program in PPKD of East Jakarta using Goal Free Evaluation, the results showed that almost all graduates who had a positive impact after beauty training were those from the socialization component they saw on the web, from the selection component, they fulfill the registration requirements and follow the selection path, from the implementation component they undergo good training without any obstacles, from the certification component to follow the PPKD competency test and BNSP competency test and pass. From the marketing component they get jobs from PPKD, from the monitoring component they continue to establish communication with PPKD and get job vacancies from whatsApp group. Therefore there were no obstacles faced by the training participants so that they had the expected positive impact from the goal of the beauty training program. 


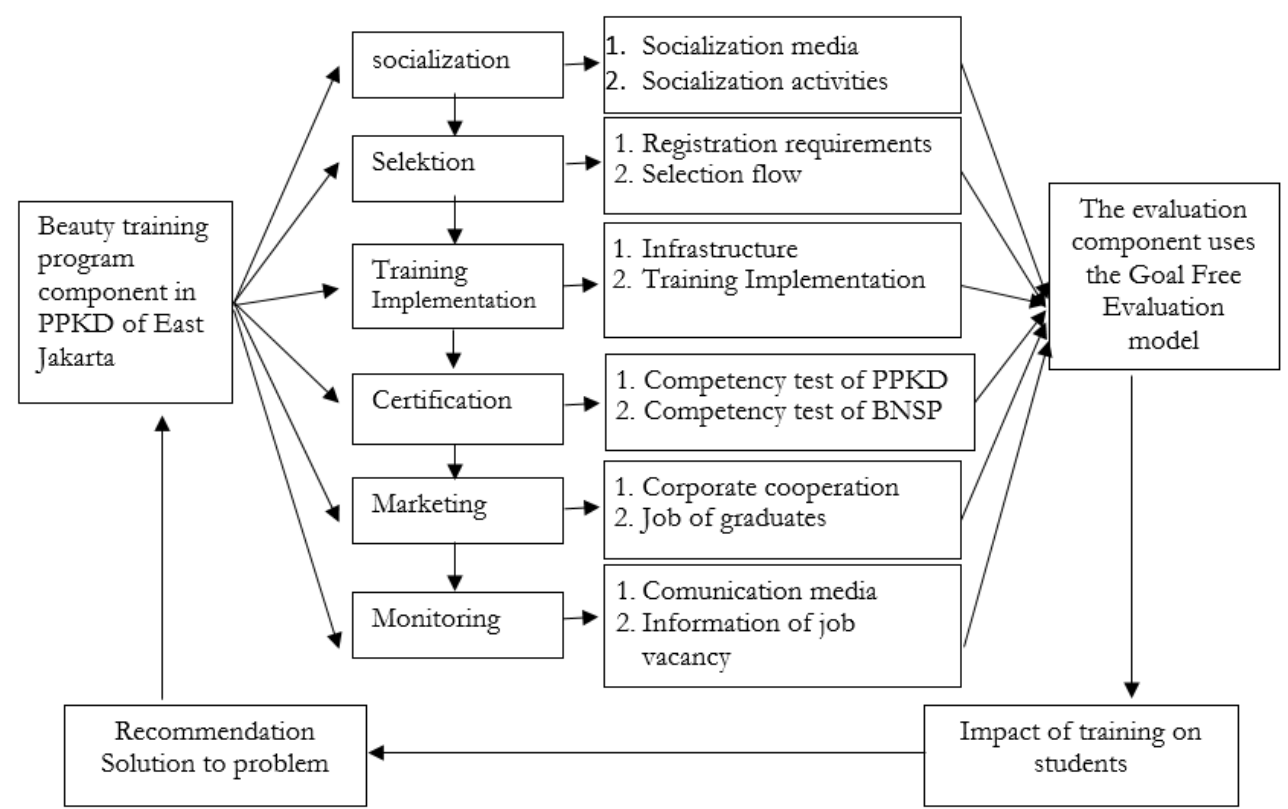

Figure 3. Evaluation of a beauty training component in PPKD of East Jakarta

Table 1. Evaluation Results of Beauty Training Components in PPKD of East Jakarta

\begin{tabular}{|c|c|c|c|c|}
\hline No & Component & Aspek & Kriteria evaluasi & Hasil evaluasi \\
\hline 1 & Sosialisation & $\begin{array}{l}\text {-Media sosialisasi } \\
\text {-Kegiatan sosialisasi }\end{array}$ & $\begin{array}{l}\text { There is appropriate media and } \\
\text { there are socialization activities } \\
\text { carried out by PPKD }\end{array}$ & $\begin{array}{l}\text { PPKD promotes training } \\
\text { through the web and } \\
\text { brochures } \\
\text { PPKD conducts } \\
\text { socialization to certain areas } \\
\text { in the kelurahan }\end{array}$ \\
\hline 2 & Selektion & $\begin{array}{l}\text {-Syarat pendaftaran } \\
\text {-Alur seleksi }\end{array}$ & $\begin{array}{l}\text { Students fulfill the registration } \\
\text { requirements and follow the } \\
\text { selection path according to the } \\
\text { procedure }\end{array}$ & $\begin{array}{l}\text { There are some students } \\
\text { who do not meet the } \\
\text { registration requirements } \\
\text { and do not follow the } \\
\text { selection path }\end{array}$ \\
\hline 3 & $\begin{array}{l}\text { Training } \\
\text { Implementa } \\
\text { tion }\end{array}$ & $\begin{array}{l}\text {-Infrastructure } \\
\text {-Training } \\
\text { Implementation }\end{array}$ & $\begin{array}{l}\text { There are facilities that support the } \\
\text { training and training process to run } \\
\text { well }\end{array}$ & $\begin{array}{l}\text { The infrastructure provided } \\
\text { is damaged and the training } \\
\text { process is a bit constrained }\end{array}$ \\
\hline 4 & Sertifikasi & $\begin{array}{l}\text {-Competency test of } \\
\text { PPKD } \\
\text {-Competency test of } \\
\text { BNSP }\end{array}$ & $\begin{array}{l}\text { Students can pass the competency } \\
\text { tests of PPKD and BNSP }\end{array}$ & $\begin{array}{l}\text { All students take the } \\
\text { competency test of PPKD } \\
\text { and BNSP and they can } \\
\text { graduate }\end{array}$ \\
\hline 5 & Marketing & $\begin{array}{l}\text {-Corporate cooperation } \\
\text {-Job of graduates }\end{array}$ & $\begin{array}{l}\text { PPKD cooperates with the work } \\
\text { industry to market graduates and } \\
\text { graduates to get jobs }\end{array}$ & $\begin{array}{l}\text { PPKD has no permanent } \\
\text { cooperation with the beauty } \\
\text { industry so that most } \\
\text { graduates get their own jobs }\end{array}$ \\
\hline 6 & Monitoring & $\begin{array}{l}\text {-Comunication media } \\
\text {-Information of job } \\
\text { vacancy }\end{array}$ & $\begin{array}{l}\text { There is a communication medium } \\
\text { that maintains communication } \\
\text { links between graduates and the } \\
\text { PPKD and PPKD informs each } \\
\text { job opening to graduates }\end{array}$ & $\begin{array}{l}\text { There are whatsApp groups } \\
\text { that can establish } \\
\text { communication links } \\
\text { between graduates and } \\
\text { PPKD parties and if there } \\
\text { are job information that is } \\
\text { informed through the } \\
\text { WhatsApp group }\end{array}$ \\
\hline
\end{tabular}




\section{Positive Impact Outside the Program Objectives (Side Effects)}

Based on interviews with 15 trainees, evaluating the implementation of the beauty training program in PPKD of East Jakarta using Goal Free Evaluation, the results showed that almost all graduates also had side effects after beauty training, namely those of all components fulfilling the evaluation criteria, but the difference in The implementation component obtained data that they were more enthusiastic and earnest so that the knowledge and skills obtained were in accordance with what they wanted and the marketing component obtained data that they were not only dependent on the promotion of jobs provided by PPKD, but they were able to get jobs, most of these informants received freelance as makeup artists (MuA), had confidence in work and some established businesses in the beauty sector such as salons and makeup studios.

\section{Negative Impact Outside the Program Objectives}

Based on interviews with 15 trainees, evaluating the implementation of the beauty training program in PPKD of East Jakarta using Goal Free Evaluation, the results showed that only a few of the graduates had a negative impact after beauty training, namely those from the socialization component they got from friends or acquaintances. from the selection component they did not meet the registration requirements and followed the selection flow because the reason for meeting the quota of prospective training participants was immediately passed, from the implementation component they were trained in earnest so that the knowledge and skills taught could not be well received, from the certification component PPKD competency test and BNSP competency test and pass but cannot use the certificate properly, from the marketing component they do not get a job from PPKD because it is inconclusive to be promoted, and from the monitoring component they do not in communication with PPKD and get job info from whatsApp group but ignore it. Therefore, the training participants could not develop their potential or human resources to enter the world of work in the field of beauty so that they did not get jobs.

\section{CONCLUSION}

The results of this study shows that, in general, that the implementation of the beauty training program in PPKD of East Jakarta has been going well but there are still shortcomings, including: (1) in the socialization component, the PPKD has promoted beauty training through websites and brochures, as well as socializing beauty training in existing villages in East Jakarta, (2) the selection component showed that the registration requirements and selection path of the training participants were not all according to the procedures that were supposed to, (3) in the training implementation component the results provided were damaged and the training process was limited, (4) the certification component obtained results that all students take the PPKD competency test and BNSP can pass, (5) in the marketing component the results show that there is no permanent collaboration with the beauty industry so that most graduates get their own jobs, and (6) the monitoring component has il that there are WhatsApp groups that can establish communication links between graduates and PPKD parties and if there are job information that is informed through the WhatsApp group.

Although in general it is said that the PPKD of East Jakarta beauty training program has been going well, there have been impacts on the training participants after attending beauty training. These impacts include: (1) the positive impact according to the program objectives is felt by almost all training participants, namely they can increase knowledge and skills in the field of beauty so that they are ready to enter the workforce, (2) a positive impact outside the program objectives freelance work as a makeup artist, having selfconfidence in work, having confidence in work, and daring to open a business in the field of beauty, (3) negative impacts outside the program's objectives were felt by a small number of participants who were less serious and focused on training ie they did not can receive the material taught so it is not ready to enter the workforce.

Based on the results of the evaluation of training components and the impact of the training participants after participating in beauty training at PPKD of East Jakarta, there were several recommendations that researchers 
could provide to improve the implementation of beauty training and there were no negative impacts felt by trainees, including: (1) Recommendations on the socialization component should be more active in promoting training through print media such as newspapers and magazines and through social social media such as Facebook, Instagram, Twitter and other social media that are widely used by the public. (2) Recommendations on the selection component should the PPKD tighten the qualifications of the registration requirements and really require that prospective procedure participants who should have. (3) Recommendations on the implementation component of the training should provide the infrastructure that is complete and still functioning properly so that the training process can run smoothly. (4) Recommendations on the certification component are only input so that the certificate should be out faster and the validity period is longer. (5) Recommendations on the marketing component should PPKD establish more cooperation with the beauty industry so that graduates can find jobs more easily through PPKD. (6) Recommendations on the monitoring component are only a little input so that the PPKD is more active in giving job information to graduates through the whatsApp group created.

\section{REFERENCE}

Badan Pusat Statistik Provinsi Daerah Khusus Ibu Kota Jakarta. (2017). https://jakarta.bps.go.id/

Hanafi, I. (2013). Re-orientasi keterampilan kerja lulusan pendidikan kejuruan. Jurnal Pendidikan Vokasi, 2(1). doi:https://doi.org/10.21831/jpv.v2i1.10 21
Gubernur Daeraha Khusus Ibu Kota Jakarta. Peraturan Gubernur Nomor 33 Tahun 2015 tentang Pembentukan, Organisasi dan Tata Kerja Pusat Pelatihan Kerja Daerah (PPKD) Jakarta Timur. (2015)

Miles, M., \& Huberman, A. (1994). Miles and Huberman Chapter 2. In Qualitative Data Analysis.

Ramadhania, M. N. (2016). Efektivitas Program Pelatihan Kecakapan Hidup (Life Skill) Bidang Tata Rias Pengantin Pada Remaja Putus Sekolah Di Lembaga Kursus Dan Pelatihan (LKP) Kota Cimahi Provinsi Jawa Barat, 2.

Rubito. (2016). Evaluasi Program Sekolah Unggulan SMAN 2 Sangatta Utara Kabupaten Kutai Timur Suatu Model Evaluasi Dengan Pendekatan Tujuan Independen (Goal Free Evaluation ), 7.

Scriven, M. (1991). Prose and Cons about Goal-Free Evaluation. American Journal of Evaluation. https://doi.org/10.1177/10982140910120 0108

Stufflebeam, D. L., \& Coryn, C. L. S. (2015). Evaluation, Theory, Models \& Application. Jossey-Bass. https://doi.org/10.1093/ecam/nep169

Suyono. (2014). Pembangunan masyarakat. Bandung : Rosda Karya

Youker, B. W., Ingraham, A., \& Bayer, N. (2014). An assessment of goal-free evaluation: Case studies of four goalfree evaluations. Evaluation and Program Planning. https://doi.org/10.1016/j.evalprogplan.20 14.05.002 